\title{
Lausunnonantajat vuonna 2020
}

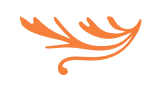

Vuonna 2019 Aikuiskasvatuksessa julkaistiin

12 vertaisarvioitua tiedeartikkelia. Lisäksi toimituskunta

käsitteli useita artikkelikäsikirjoituksia. Kiitämme lämpimästi lausunnonantajia!

Helle Laura, PhD, dosentti, opettajankoulutuslaitos, Turun yliopisto

Holma Katariina FT, kasvatustieteen professori, kasvatustieteiden tiedekunta, Oulun yliopisto

liskala Tuike, KT, opettajankoulutuslaitos, Turun yliopisto

Jokisaari Olli-Jukka, FT, lehtori, Turun kaupungin opetustoimi

Kantola Tarja, FT, yliopettaja, Laurea-ammattikorkeakoulu

Keurulainen Harri, KL, yliopettaja, ammatillinen opettajakorkeakoulu, Jyväskylän ammattikorkeakoulu

Komulainen Katri, PsT, professori, kasvatustieteiden ja psykologian osasto, Itä-Suomen yliopisto

Koskela Teija, KT, yliopistotutkija, opettajankoulutuslaitos, Turun yliopisto

Käyhkö Mari, YTT, dosentti, yhteiskuntatieteiden laitos, Itä-Suomen yliopisto

Laiho Anne, KT, dosentti, kasvatustieteiden laitos, Turun yliopisto

Martikainen Soili TkT, lehtori, Laurea-ammattikorkeakoulu

Mietola Reetta, KT, dosentti, kulttuurien osasto, humanistinen tiedekunta, Helsingin yliopisto

Muhonen Reetta YTT, dosentti, Turun tutkijakollegium (TIAS), kasvatustieteiden laitos, Turun yliopisto

Ojala Kristiina, KT, kasvatustieteiden laitos, Turun yliopisto

Ojanen Markku, YTT, psykologian emeritusprofessori, Tampereen yliopisto

Oksanen Markku, VTT, dosentti, yhteiskuntatieteiden laitos, Itä-Suomen yliopisto

Paavola Sami, FT, apulaisprofessori, kasvatustieteellinen tiedekunta, Helsingin yliopisto,

Paloniemi Susanna, KT, kasvatustieteiden laitos, Jyväskylän yliopisto 
Peltola Raija, OTK, työnohjaaja, valmentaja, Tevere Oy

Postareff Liisa, KT, dosentti, HAMK Edu tutkimusyksikkö, Hämeen ammattikorkeakoulu

Puukari Sauli, KT, dosentti, opettajankoulutuslaitos, Jyväskylän yliopisto

Pylväs Laura, KT, tutkijatohtori, kasvatustieteellinen tiedekunta, Helsingin yliopisto

Saarinen Taina, FT, tutkimusprofessori, Koulutuksen tutkimuslaitos, Jyväskylän yliopisto

Salminen Hanna VT, viestintäjohtaja, valmentaja, Hengitysliitto

Siekkinen Taru, FT, Koulutuksen tutkimuslaitos, Jyväskylän yliopisto

Siivonen Päivi, FT, filosofinen tiedekunta, Itä-Suomen yliopisto

Souto Anne-Mari, YTT, KM, yliopistonlehtori, filosofinen tiedekunta, ItäSuomen yliopisto

Suoranta Juha, KT, yhteiskuntatieteiden tiedekunta, Tampereen yliopisto

Suorsa Teemu, KT, yliopistonlehtori, kasvatustieteiden tiedekunta, Oulun yliopisto

Tammi Tuure, FT, kasvatustieteiden tiedekunta, Oulun yliopisto

Tervasmäki Tuomas KM, väitöskirjatutkija, kasvatustieteiden ja kulttuurin tiedekunta, Tampereen yliopisto

Vaahtera Touko, FT, yhteiskuntatieteiden laitos, Itä-Suomen yliopisto

Varjo Janne, KT, apulaisprofessori, kasvatustieteellinen tiedekunta, Helsingin yliopisto

Viren Eetu, YTT, vapaa suomentaja

Virtanen Anne, KT, Koulutuksen tutkimuslaitos, Jyväskylän yliopisto

\section{Refereepolitiikka}

Aikuiskasvatukseen tarjotut tiedeartikkelit käsitellään anonyymeina ja lähetetään mahdollisten muutospyyntöjen jälkeen kahdelle ulkopuoliselle asiantuntijalle arvioitavaksi. Arvioitsijat pysyvät kirjoittajille anonyymeinä, eikä kirjoittajan henkilöllisyyttä paljasteta arvioitsijoille.

Arvioinnin tavoite on antaa kirjoittajalle ehdotuksia ja neuvoja artikkelin parantamiseksi. Hyödyllisintä on rehellinen, kriittinen, käytännöllinen ja kannustava palaute. Referee arvioi seuraavia seikkoja:

- tutkimusaiheen merkityksellisyys, kiinnostavuus ja tärkeys

- kirjoittajan asiantuntemus
- tutkimusasetelma ja -menetelmät, lähdeaineisto, tutkimuksen toteutus ja käytetty tutkimuskirjallisuus suhteessa tutkimuskysymykseen

- tieteellinen taso

- sisällöllinen arvo ja uutuusarvo

- argumentoinnin vakuuttavuus

- kokonaisuus suhteessa otsikon ja aloituksen asettamiin odotuksiin

- esitystavan johdonmukaisuus

- luettavuus ja selkeys

- kuvioiden ja taulukoiden toimivuus. 